\title{
Integrated multilevel converter and battery management
}

\author{
K. Wilkie, D. Stone, C. Bingham, M. Foster \\ University of Sheffield, EEE, Mappin Street, Sheffield S1 3JD, (UK)
}

\begin{abstract}
A cascaded H-bridge multilevel converter is proposed as a BLDC drive incorporating real-time battery management. Intelligent $\mathrm{H}$-bridges are used to monitor battery cells whilst simultaneously increasing their performance by reducing the variation between cells and controlling their discharge profiles.
\end{abstract}

\section{Index Terms - Multilevel Systems, Motor Drives}

\section{NOMENCLATURE}

$V_{\text {cell }(A, B, C)}-$ Cell voltage $(\mathrm{A}, \mathrm{B}$ or $\mathrm{C})$

$\mathrm{I}_{\text {cell }(A, B, C)}-$ Cell current (A, B or C)

SoC - State of Charge

\section{INTRODUCTION}

Recent publications have considered the relative merits of battery technologies and have reported that a key problem with the use of lead acid batteries (the current favoured solution on the basis of cost) as the main energy store within hybrid vehicles, is that they are subjected to high charge and discharge rates when under partial state of charge (SoC) conditions. This leads to sulphate build-up, cyclic wear, and ultimately, to failure $[1,2]$. In this paper, therefore, the mitigation of such problems is considered using 'intelligent control' techniques to better utilize the battery and, thereby, enhance performance and longevity.

This paper investigates the integration of a cascaded H-bridge multilevel converter with real-time battery management to control SoC. The cascaded H-bridge converter facilitates superior electrical output behaviour with reduced current ripple, when compared to traditional six-switch inverter solutions.

\section{Multilevel CASCADED H-BRIDGE}

The cascaded H-bridge multilevel converter topology, Fig. 1, is formed by the series connection of a number of full $\mathrm{H}$-bridge converters. This topology naturally isolates each battery cell facilitating battery management, for use in applications such as the hybrid vehicle where isolated battery cells are available.

Each H-bridge cell is capable of producing $0,+V_{\text {cell }}$ or $-V_{\text {cell }}$, with or without pulse width modulation. The output of the converter is the contribution from all the individual cells.

This work was supported by the UK EPRSC via the provision of a research studentship.
The reduced voltage levels produce more accurately synthesized output waveforms with lower harmonic distortion reducing filtering requirements, and switch voltage stresses. These more widely known advantages to the multilevel topology are reported in literature [3, 4].

Current ripple and its minimization is an important factor in traction applications, where the associated torque ripple is undesirable. The reduction in voltage levels reduces the voltage seen by the inductive load and therefore current ripple. To achieve this with the standard 2-level converter would require an increase in switching frequency and associated switching losses. This leads to the multilevel converter being suitable for low inductance machines [5], or for reducing current ripple in standard machines [6].

This paper specifically investigates the battery management aspects afforded by isolation of the battery sources.
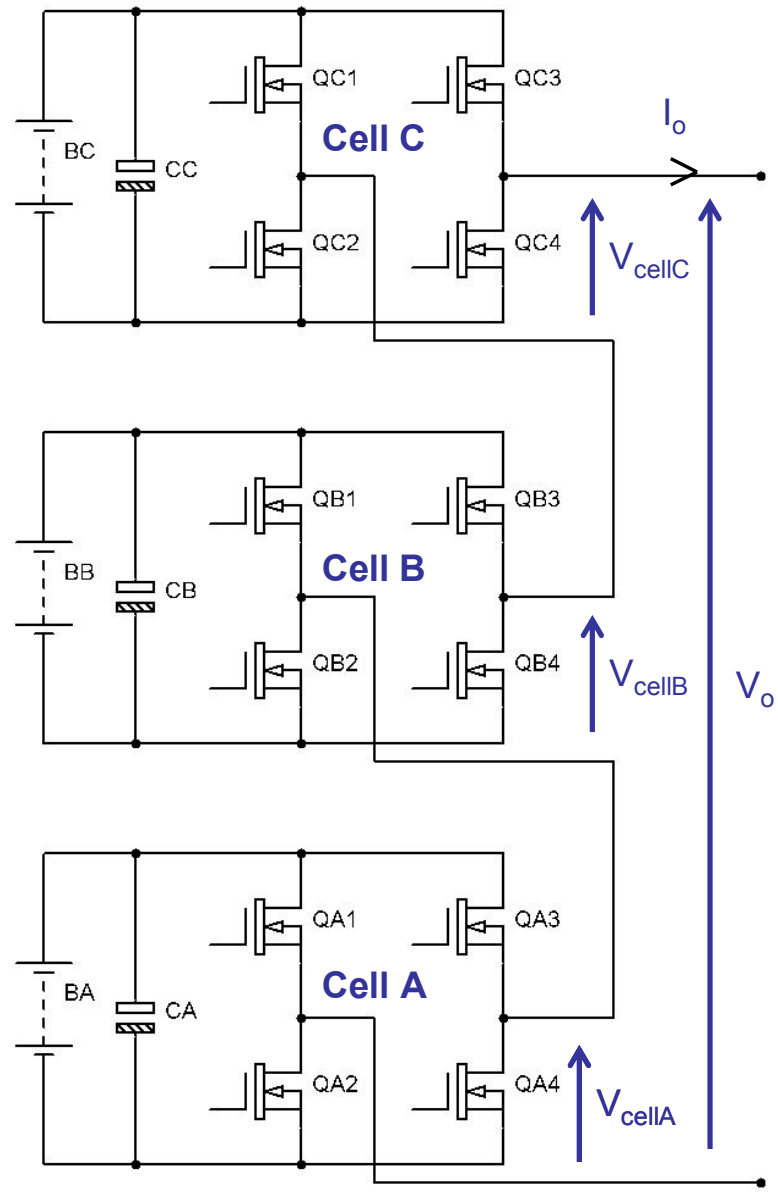

Fig. 1. 7-level cascaded H-bridge 


\section{PRototype System}

\section{A. Prototype Hardware}

A BLDC drive system is realized with 'intelligent' $\mathrm{H}$-bridge cells performing SoC estimation and capable of producing PWM. These, combined with a phase controller, achieve current control and battery management. For comparison purposes, and as a proof of principle, only one phase is controlled in this manner, with a 6-switch inverter then providing commutation, reducing the phase requirement of the multilevel converter whilst facilitating the battery management. A block diagram of the system is shown in Fig. 2.

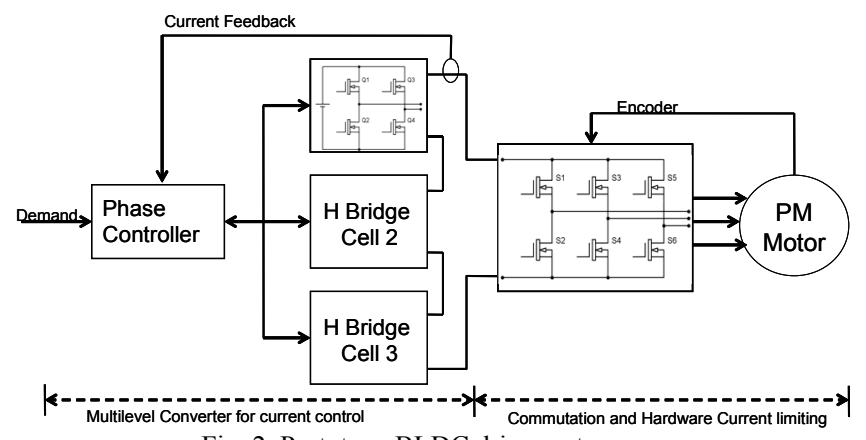

Fig. 2. Prototype BLDC drive system

Experimental results are obtained from a prototype 7level multilevel converter using $3 \times 12 \mathrm{~V}$, 45Ah lead acid batteries, driving a $1.2 \mathrm{~kW}$ BLDC machine. The experimental setup is shown in Fig. 3. The BLDC machine is used in a dynamometer rig, with a brushed DC machine and resistive load.

The prototype uses three identical cells on a common SPI interface bus, providing a modular, easily expandable system.

Each H-bridge cell comprises of an embedded microprocessor (PIC18F2431) producing PWM, sampling cell voltage and current whilst performing SoC calculation. The switching devices used are the FQA170N06 rated at $60 \mathrm{~V}, 170 \mathrm{~A}$, an opto-isolated communication bus, power supplies and protection circuitry.

The phase controller is based on a dsPIC30F4011, which calculates the required cell states and duty cycle for a given demand signal and maps this to the cell priority based on the battery management algorithm. An RS232 link is implemented so cell voltage, current and the current integration can be communicated to Simulink, which acts as a data logger, and Stateflow, which implements the various battery management techniques.

\section{B. SoC Estimation}

$\mathrm{SoC}$ estimation in the form of current integration is implemented on each of the H-bridge cells. This is communicated to the phase controller and passed on to a PC, which performs the battery management using Stateflow.

Initial $\mathrm{SoC}$ is estimated from the open circuit cell voltage before testing begins. A linear first order approximation of a lead acid model, consisting of a bulk capacitance and series resistance, is used in the initial SoC estimate, and is a simplification of Randles' model presented in [7]. The model parameters are obtained from experimental drive cycle data. The SoC is then calculated in Simulink using the estimated initial SoC and current integration value.

Ultimately the battery management will be implemented on the phase controller, producing a system that incorporates battery management but the only user required input is that of an analogue demand signal.

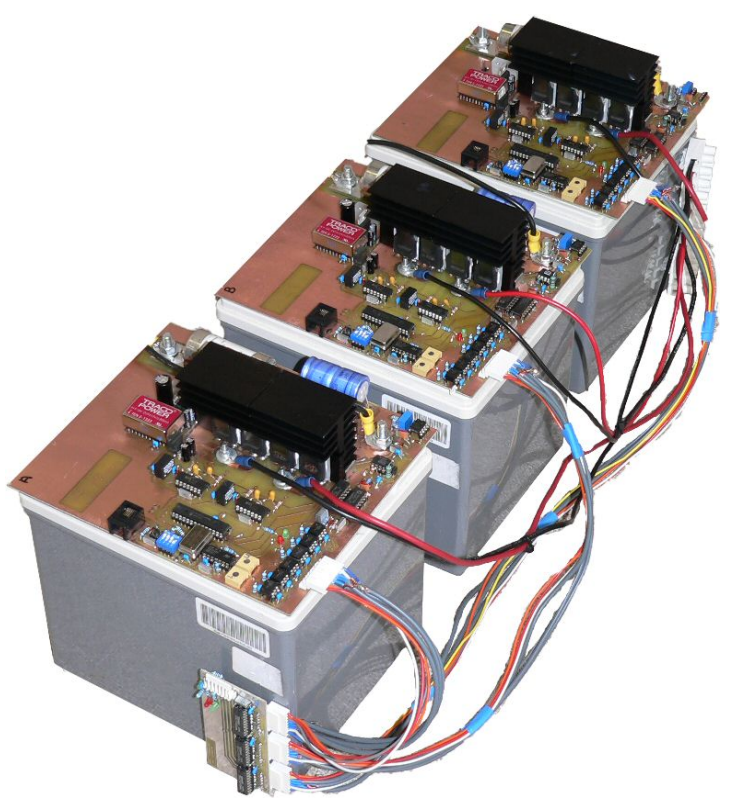

Fig. 3. 7-level prototype hardware

\section{BATTERY MANAGEMENT}

The hybrid electric vehicle utilizes a series connection of batteries to form a battery pack. The electrical performance of this pack can deteriorate over time when exposed to differing charge and discharge rates as well as $\mathrm{SoC}$ variations within the pack.

Methods for charge balancing within a multilevel converter are presented in [8]. These are extended in [6] with the application of SoC estimation and investigated with simulations.

Without battery management the cells will discharge unequally with the cell producing the lowest levels discharging most quickly with no account being made for initial conditions.

\section{A. Balanced Discharge}

The first method investigated here is that of balanced discharge or cell rotation where the load to each cell is balanced by rotating the demand between the available cells. This is shown in Fig. 4(a). Literature suggests rotating the demand every half cycle of the output frequency, when producing $\mathrm{AC}$ waveforms, to balance the load. However, with a DC load, and due to the large electrical time constant of the lead acid battery, it has 
been found beneficial to perform the rotation at $30 \mathrm{~s}$ intervals.

Balanced discharge, Fig. 4, equalizes the load to each battery, as demonstrated by the parallel SoCs, but does not take into account initial conditions. Cell $\mathrm{C}$ has the lowest $\mathrm{SoC}$ at the beginning and end of the test.

\section{B. SoC Based Scheme}

The variation of SoC due to initial conditions can be reduced with a $\mathrm{SoC}$ based scheme, where the $\mathrm{SoC}$ is taken into account and the cell with the lowest $\mathrm{SoC}$ is used last, thus equalizing the SoC before applying a balanced discharge. This is shown in Fig. 4(b) where the cells SoC converge. When cells become equal the demand is rotated between them thereby balancing the discharge.

The output of the converter is adjusted for both the balanced discharge and SoC based scheme to produce a nominal $D C_{\text {Link }}$ current of $10 \mathrm{~A}$.
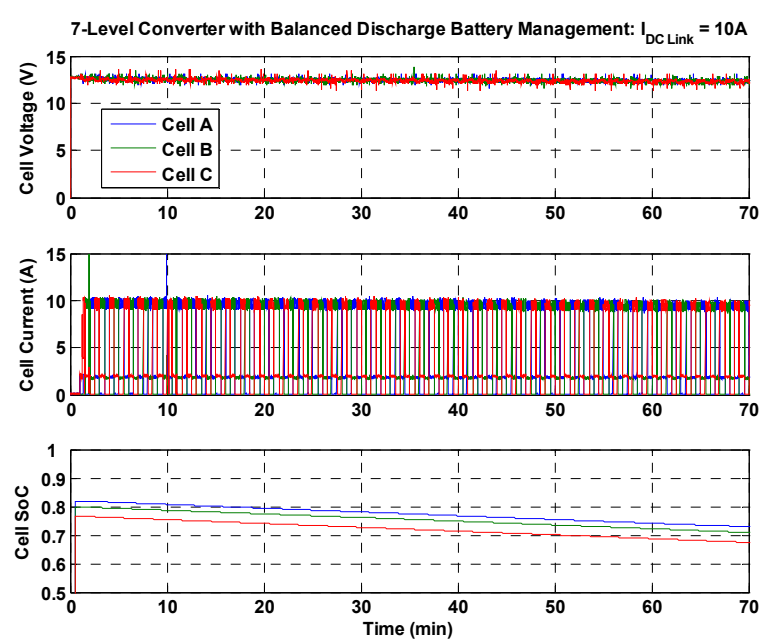

(a)
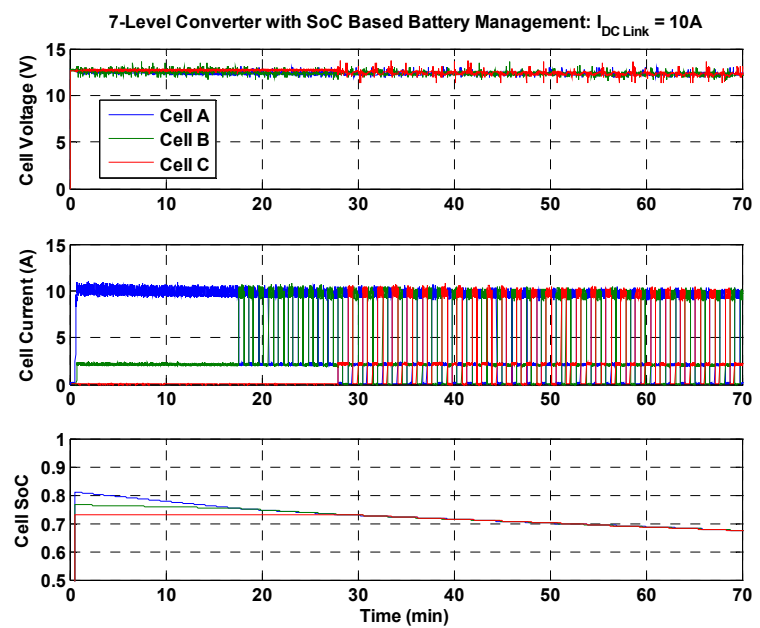

(b)

Fig. 4. Experimental results, (a) 7-level converter with balanced discharge, (b) 7-level converter with SoC based battery management

\section{COMPARISON WITH 2-LEVEL CONVERTER}

To demonstrate the improvements achievable with the multilevel converter, the classical 2-level converter is presented for comparison. The motor phase current is adjusted to give the same current, Fig. 5, for both converters. The power delivered to the load is $166 \mathrm{~W}$. Fig. 5 also demonstrates the current ripple reduction by virtue of using smaller voltage levels in the multilevel converter when compared to a classical 2-level system.

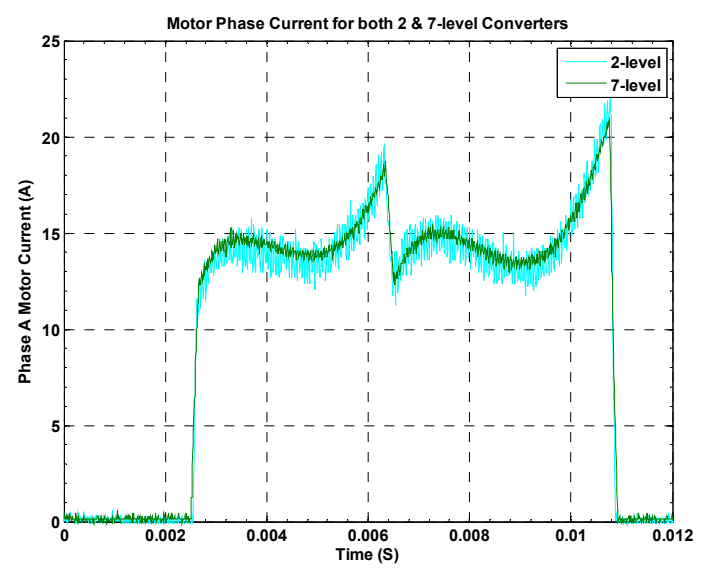

Fig. 5. Motor phase current with 2-level and 7-level converters

\section{1) 2-level Converter}

First the effects of differing initial conditions and cell deterioration are investigated with the classical 2-level converter. The battery cells are connected in series to form the DC link for a standard 2-level converter, the same switching frequency, $20 \mathrm{kHz}$, being used for both converters.

The battery used in cell A is aged and offers a reduced capacity to that of cells $\mathrm{B}$ and $\mathrm{C}$. The battery cells voltage current and estimated SoC is shown in Fig. 6(a).

\section{2) 7-level Converter}

Under the same conditions the 7-level converter test data is shown in Fig. 6(b).

The initial SoC differs with both types of converter, however, with the 7-level converter they are equalized after $19 \mathrm{~min}$ of operation, whereas with the 2-level converter they remain different. In the 2-level converter the lower capacity cell A fails, the cell voltage falls rapidly, after $55 \mathrm{~min}$ of operation. This is extended to $\sim 76 \mathrm{~min}$ with the 7-level converter with the failure being gradual as the load is balanced between cells.

The battery management using the 7-level converter can be extended further by taking remedial action should any cell degrade. That cell can then be bypassed and the demand rotated between the remaining available cells. The maximum output will be reduced but the drive can continue to operate. 

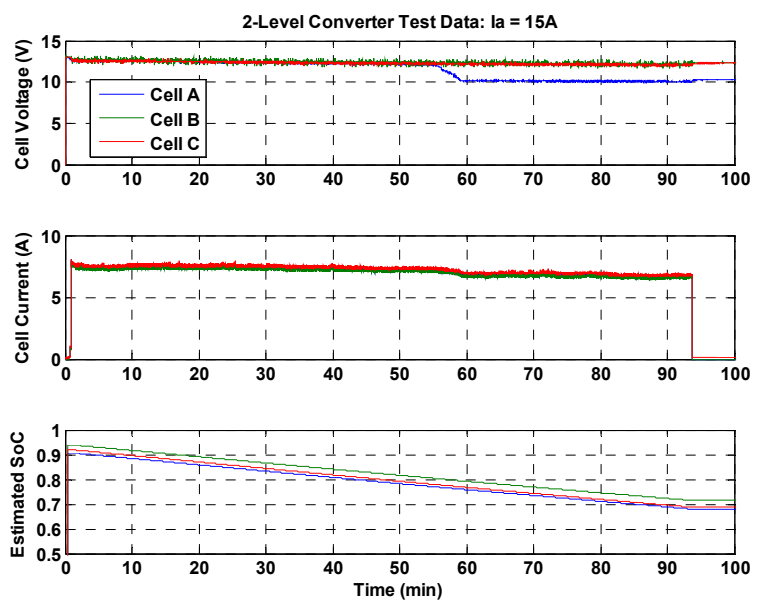

(a)
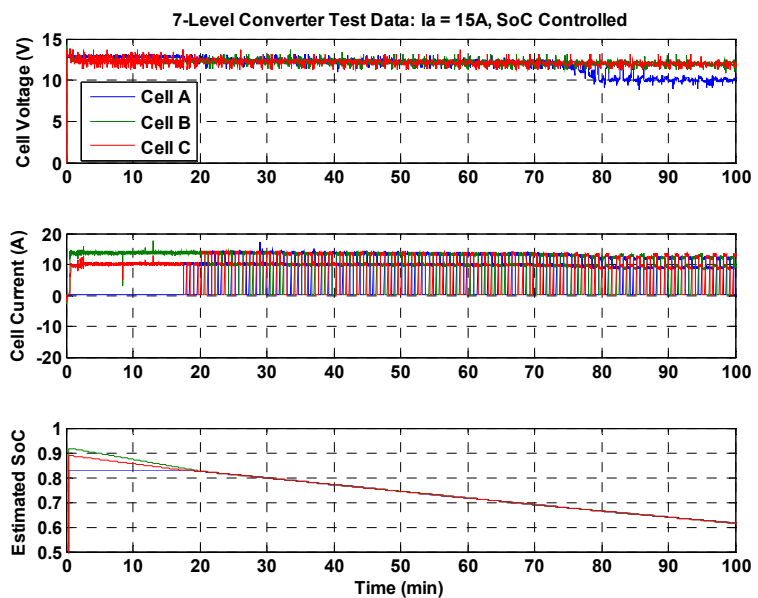

(b)

Fig. 6. Experimental results, (a) 2-level converter, (b) 7-level converter with SoC based battery management

\section{CLOSED-LOOP CONTROL}

Preliminary results with a PI current controller are presented in Fig. 7, demonstrating the capability to control output current whilst incorporating the SoC based battery management. This avoids the fall in output current, caused by the reduction in cell voltage as battery SoC decreases, as seen in Fig. 6(a,b).

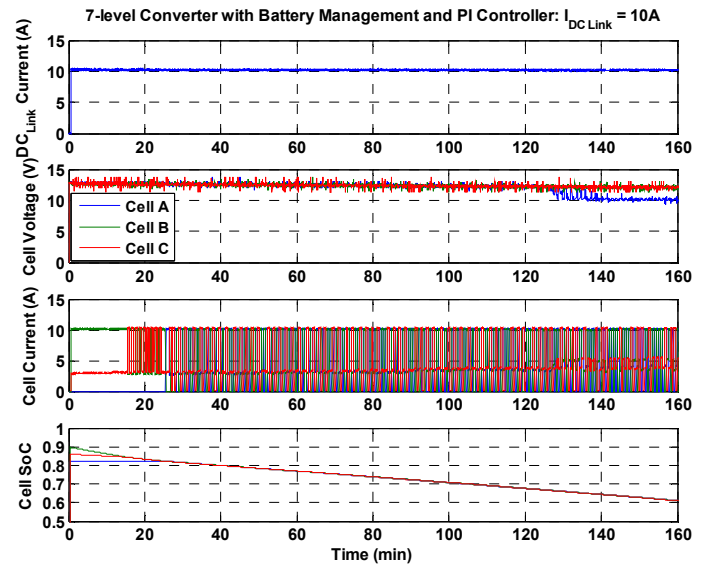

Fig. 7. 7-level converter with SoC battery management and current control

\section{DISCUSSION}

Experimental results presented here use different battery management techniques, both of which offer improvements over the cascaded H-bridge without management. Balance discharge between cells is achieved, before improvement, with a SoC based scheme that is capable of equalizing SoC before balancing the discharge.

The proposed 7-level BLDC drive, incorporating battery management, has been demonstrated to increase battery running time over the classical 2-level converter.

Extensions to this work include the performing of remedial action should any cell fail, and improvements to SoC estimation, using observer techniques, to track the initial SoC and to take into account variation of cell parameters.

Further work will investigate the transfer of energy between cells, to facilitate an off-line equalization and cell conditioning routine, as well as the application of battery management techniques to battery charging.

\section{CONCLUSIONS}

Improvement in battery performance has been presented in the cascaded H-bridge multilevel converter when compared with the classical 2-level converter. This was demonstrated by showing reduced variation between cells with real-time battery management techniques.

\section{ACKNOWLEDGMENT}

The authors would like to thank the EPSRC for sponsoring this work as part of a PhD study.

\section{REFERENCES}

[1] L. T. Lam, N. P. Haigh, C. G. Phyland, and A. J. Urban, "Failure mode of valve-regulated lead-acid batteries under high-rate partial-state-of-charge operation," Journal of Power Sources, vol. 133, pp. 126-134, 2004.

[2] E. Karden, S. Ploumen, B. Fricke, T. Miller, and K. Snyder, "Energy storage devices for future hybrid electric vehicles," Journal of Power Sources, vol. 168, pp. 2-11, 2007.

[3] J. Rodriguez, J.-S. Lai, and F. Z. Peng, "Multilevel inverters: A survey of topologies, controls, and applications," IEEE Transactions on Industrial Electronics, vol. 49, pp. 724-738, 2002.

[4] L. Jih-Sheng and P. Fang Zheng, "Multilevel converters-a new breed of power converters," Industry Applications, IEEE Transactions on, vol. 32, pp. 509-517, 1996.

[5] G. J. Su and D. J. Adams, "Multilevel DC link inverter for brushless permanent magnet motors with very low inductance," Chicago, IL, 2001, pp. 829-834.

[6] K. D. Wilkie, D. A. Stone, M. P. Foster, and C. M. Bingham, "A Cascaded H-Bridge BLDC Drive Incorporating Battery Management," in EPE, Aalborg, 2007.

[7] B. S. Bhangu, P. Bentley, D. A. Stone, and C. M. Bingham, "Observer Techniques to estimate the State of Charge of Valve Regulated Lead Acid Batteries for Hybrid Electric Vehicles," in IEEE Proceedings Vehicle Power and Propulsion, Chicago, 2005.

[8] L. M. Tolbert, F. Z. Peng, T. Cunnyngham, and J. N. Chiasson, "Charge balance control schemes for cascade multilevel converter in hybrid electric vehicles," IEEE Transactions on Industrial Electronics, vol. 49, pp. 10581064, 2002. 